\title{
Optimalisasi Model ARCS dalam Pembelajaran Tematik Untuk Meningkatkan Motivasi Belajar Peserta Didik di MI At-Taqwa Bondowoso
}

\author{
Sinta Yulis Pratiwi \\ MI At-Taqwa Bondowoso \\ sintapratiwi708@gmail.com \\ DOI: 10.35719/educare.v2i2.53
}

\begin{abstract}
This study aims to explain the optimization of the ARCS learning model as an effort to increase the learning motivation of students, especially in thematic learning at MI At-Taqwa Bondowoso. The method used is qualitative with a descriptive qualitative approach, while the type of research used in this research is field research. The data collection techniques used interviews, observation, and documentation. Data analysis used was condensation, data presentation, and verification. And the validity of the data uses triangulation of sources and techniques. The results of this study indicate (1) Thematic Learning Problems at MI At-Taqwa Bondowoso, namely: Teachers are less biased in utilizing learning media, so that the only sources used are textbooks, classroom learning is only centered in the teacher, the students' lack of interest in the learning process, so that students do not pay attention to the teacher who teaches. (2) The application of the ARCS model in thematic learning at MI AtTaqwa Bondowoso, namely: The implementation of the ARCS model was carried out by teachers with several methods and strategies such as modeling the way strategy and also contextual teaching and learning, ARCS Model as an alternative solution in learning for increasing students 'learning motivation is able to stimulate students' enthusiasm in thematic learning.
\end{abstract}

Keywords: ARCS Model; Thematic Learning; Motivation to Learn 


\begin{abstract}
Abstrak
Penelitian ini bertujuan untuk menjelaskan optimalisasi model pembelajaran ARCS sebagai upaya meningkatkan motivasi belajar peserta didik khususnya dalam pembelajaranTematik di MI At-Taqwa Bondowoso. Metode yang digunakan adalah kualitatif dengan pendekatan kualitatif deskriptif, sedangkan jenis penelitian yang digunakan dalam penelitian ini adalah penelitian lapangan (field research). Adapun teknik pengumpulan data menggunakan wawancara, observasi, dan dokumentasi. Analisis data yang digunakan yakni kondensasi, penyajian data, dan verifikasi. Dan keabsahan datanya menggunakan triangulasi sumber dan teknik. Hasil penelitian ini menunjukkan (1) Problematika Pembelajaran Tematik di MI At-Taqwa Bondowoso, yaitu: Guru kurang biasa memanfaatkan media pembelajaran, sehingga sumber yang dipakai hanya buku ajar saja, Pembelajaran di kelas hanya berpusat pada guru, Kurangnya ketertarikan peserta didik dalam proses pembelajaran, sehingga peserta didik tidak memperhatikan guru yang mengajar. (2) Penerapan model ARCS dalam pembelajaran tematik di MI At-Taqwa Bondowoso, yaitu: Penerapan model ARCS dilakukan oleh para guru dengan beberapa metode dan strategi seperti strategi modeling the way dan juga contextual teaching and learning, Model ARCS sebaga solusi altenatif dalam pembelajaran untuk meningkatakn motivasi belajar peserta didik mampu merangsang semangat peserta didik dalam pembelajaran tematik.
\end{abstract}

\title{
Kata Kunci: Model ARCS; Pembelajaran Tematik; Motivasi Belajar
}

\section{PENDAHULUAN}

Pendidikan merupakan salah satu aspek kehidupan yang sangat erat kaitannya dengan kehidupan manusia karena pendidikan merupakan salah satu pilar yang mempunyai peranan penting dalam menciptakan manusia yang berkualitas. ${ }^{1}$ Selain itu pendidikan merupakan investasi sumber daya manusia jangka panjang yang mempunyai nilai penting dan strategis bagi peradaban manusia. Hampir semua negara menempatkan pendidikan sebagai suatu hal terpenting dan utama dalam membangun suatu bangsa dan negara.

${ }^{1}$ Sinta Yulis Pratiwi and Lailatul Usriyah, "Implementasi Pendidikan Profetik Dalam Membentuk Karakter Peserta Didik Di Sekolah Dasar Al-Baitul Amien Jember". EDUCARE: Journal of Primary Education 1 (3), 2020, 245. 
Undang-Undang No.20 Tahun 2003 tentang system Pendidikan nasional menyatakan bahwa Pendidikan adalah usaha sadar dan terencana untuk mewujudkan suasana belajar dan proses pembelajaran agar peserta didik secara aktif mengembangkan potensi dirinya, untuk memiliki kekuatan spiritual keagamaan, pengendalian diri, masyarakat, bangsa, dan negara. ${ }^{2}$ Dalam proses tersebut diperlukan guru memberikan keteladanan, membangun kemauan serta mengembangkan potensi dan kreativitas peserta didik. Karena itu tujuan Pendidikan memiliki dua fungsi yaitu memberikan arah kepada segenap kegiatan pendidikan dan merupakan sesuatu yang ingin dicapai oleh segenap kegiatan pendidikan. ${ }^{3}$ Dalam pembelajaran dengan model ARCS, guru diharuskan membangun semangat dan motivasi peserta didik dalam pembelajaran. Terlebih dalam pembelajaran tematik, guru tidak hanya melakukan transfer pengetahuan saja akan tetapi juga transfer semangat dan motivasi dalam belajar.

Motivasi dan belajar merupakan dua hal yang saling mempengaruhi. Setiap anak yang lahir memiliki motivasi belajar. Motivasi berasal dari kata motif yang berarti kekuatan yang terdapat dalam diri individu, yang menyebabkan individu itu bertindak dan berbuat. ${ }^{4}$

Model pembelajaran attention, relevance, confiadence, dan satisfaction dalam proses belajar, motivasi sangat diperlukan sebab seseorang yang tidak mempunyai motivasi dalam belajar tidak akan mungkin melakukan aktivitas belajar. Hal ini merupakan pertanda bahwa sesuatu yang akan dikerjakan itu tidak menyentuh kebutuhannya, segala sesuatu yang menarik minat orang lain belum tentu menarik minat orang tertentu selama sesuatu itu tidak bersentuhan dengan kebutuhannya. Model

\footnotetext{
${ }^{2}$ Mede Pidarta, Landasan Kependidikan, (Jakarta: Rineka Cipta, 2014), 1.

${ }^{3}$ Ismail Suardi Wekke, Ridha Windi Astuti, Kurikulum 2013 di Madrasah Ibtidaiyah Implementasi di Wilayah Minoritas Muslim, (Tadris: Jurnal Keguruan dan Ilmu Tarbiyah 02, 2017), 33.

${ }^{4}$ Suranto, Pengaruh Motivasi, Suasana Lingkungan Dan Sarana Prasarana Belajar Terhadap Prestasi Belajar Peserta didik Studi Kasus Pada SMA Khusus Putri SMA Islam Diponegoro Surakarta, (Jurnal Pendidikan Ilmu Sosial, Vol 25, No.2, Desember 2015),12.
} 
pembelajaran ini berkaitan erat dengan motivasi peserta didik terutama motivasi untuk memperoleh pengetahuan yang baru. ${ }^{5}$

Menurut Scheinder, model ini sangat penting untuk pendidikan terutama pendidikan jarak jauh, ataupun peninjauan motivasi peserta didik dalam proses pembelajaran, karena motivasi merupakan faktor kunci yang menentukan apakah pelajar menyelesaikan pelatihan mereka. Model ini berfokus pada motivasi ekstrinsik dan dikembangkan untuk mendorong timbulnya motivasi intrinsik dalam diri

Sedangkan menurut Slavin, motivasi merupakan salah satu prasyarat yang paling penting dalam belajar. Bila tidak ada motivasi, proses belajar tidak akan terjadi. Motivasi dapat mempengaruhi proses dan hasil belajar. Berbeda dengan kebanyakan sekolah yang hanya menekankan pada kemampuan kognitif peserta didik dalam pembelajarannya. MI At-Taqwa Bondowoso merupakan sekolah yang tidak sekedar meningkatkan kemampuan kognitif peserta didik dalam pembelajaran. Akan tetapi, sekolah ini juga mengutamakan peningkatan motivasi dan membangun kemauan belajar peserta didik dalam pembelajaran di kelas. Motivasi peserta didik terus ditingkatkan dengan tujuan untuk merangsang semangat peserta didik untuk belajar sehingga kemampuan kognitif peserta didik pun akan berkembang jika peserta didik mampu belajar dengan bersemangat dan menyenangkan. Model ARCS digunakan oleh para guru di MI At-Taqwa Bondowoso untuk membangun kemauan dan motivasi belajar peserta didik . Dari uraian tersebut, penelitian dengan tema "Optimalisasi Model ARCS dalam Pembelajaran Tematik untuk Meningkatkan Motivasi Belajar Peserta didik di MI At-Taqwa Bondowoso" dapat memberi gambaran realitas dan solusi untuk meningkatkan motivasi belajar peserta didik di Madrasah Ibtidaiyah.

${ }^{5}$ Evaline Siregar, Teori Pembelajaran Dan Pembelajaran, (Bogor: Ghalia Indonesia, 2015), 49. 


\section{METODE PENELITIAN}

Pendekatan yang digunakan dalam penelitian ini adalah pendekatan kualitatif deskriptif. Alasan penulis menggunakan pendekatan ini sebagaimana menurut Bogdan dan Taylor dalam Moleong bahwa penelitian deskriptif kualitatif sebagai penelitian yang menghasilkan data deskriptif berupa kata-kata tertulis atau lisan dari orang-orang dan perilaku yang dapat diamati. Menurut mereka, pendekatan ini diarahkan pada latar dan individu tersebut secara holistic (utuh). ${ }^{6}$ Adapun jenis penelitian yang digunakan dalam penelitian ini adalah penelitian lapangan (field research) dengan pandangan fenomonologi karena peneliti berangkat ke lapangan untuk mengadakan pengamatan tentang suatu fenomena dalam suatu keadaan alamiah. ${ }^{7}$ Dengan ini peneliti berusaha untuk mendeskripsikan data atau kejadian yang menjadi pusat perhatian yaitu Optimalisasi model ARCS dalam pembelajaran tematik untuk meningkatkan motivasi belajar peserta didik di MI At-Taqwa Bondowoso. Adapun teknik pengumpulan data menggunakan wawancara, observasi, dan dokumentasi. Analisis data yang digunakan yakni kondensasi, penyajian data, dan verifikasi. Dan keabsahan datanya menggunakan triangulasi sumber dan teknik.

\section{HASIL DAN PEMBAHASAN TEMUAN}

Problematika Pembelajaran Tematik Sebelum Diterapkan Model ARCS Di MI At-Taqwa Bondowoso

Berdasarkan hasil observasi dan wawancara peneliti yang dilaksanakan di MI At-Taqwa Bondowoso dalam proses pembelajaran tematik, peserta didik cenderung pasif dan malu untuk bertanya tentang materi pelajaran yang telah diberikan serta kurang berani menyampaikan pendapatnya selama pembelajaran. Proses pembelajaran masih berpusat

${ }^{6}$ Lexy J Moleong, Metodologi Penelitian Kualitatif, (Bandung: Remaja Rosdakarya, 2019), 4.

${ }^{7}$ Musfiqon, Panduan Lengkap Metodologi Penelitian Pendidikan (Jakarta: Prestasi Public Publiser, 2012), 56. 
pada guru (teacher centre) serta guru belum menggunakan variasi model pembelajaran. Rendahnya aktivitas belajar peserta didik dalam mengikuti kegiatan pembelajaran tematik disebabkan diantara peserta didik yang mengobrol dengan temannya ketika guru sedang menyampaikan materi. Kurangnya ketertarikan peserta didik dalam mengikuti proses pembelajaran yang hanya menggunakan sumber belajar dari buku. Kurangnya pemanfaatan media pembelajaran yang sesuai dengan materi. Dan juga kurangnya kreatifitas guru untuk menciptakan media pembelajaran.

Guru yang mengajar telah berusaha untuk meningkatkan motivasi peserta didik dalam pembelajaran tematik dan gemar mempelajari tematik sebagaimana dijelaskan oleh guru "selama ini kami selalu berusaha untuk menigkatkan motivasi dalam pembalajaran tematik, seperti memberikan nasehat untuk rajin belajar tematik, memberikan tugas-tugas berupa pertanyaan ataupun tugas tertulis. ${ }^{8}$ Sehingga dapat disimpulkan motivasi belajar peserta didik belum masuk ke dalam kategori baik dikarenakan kurangnya kesadaran, kemauan, motivasi belajar dan keterlibatan peserta didik dalam pembelajaran, maka hasil belajar kurang maksimal.

\section{Penerapan Model ARCS Dalam Pembelajaran Tematik Di MI At- Taqwa Bondowoso}

Penerapan model ARCS di MI At-Taqwa Bondowoso dilakukan oleh para guru dengan beberapa metode dan strategi. Pemilihan model ARCS dirasa mampu untuk membangun dan meningkatkan motivasi belajar peserta didik terlebih dalam pembelajaran tematik. Penerapan model ARCS di MI At-Taqwa Bondowoso juga diterapkan dengan beberapa metode dan strategi pendukung lainnya. Salah satunya yakni strategi modeling the way dan juga contextual teaching and learning. 2020

${ }^{8}$ Hasil wawancara dengan guru Tematik, Dhiyanudin pada hari Sabtu 13 November 
Model ARCS sebaga solusi altenatif dalam pembelajaran untuk meningkatkan motivasi belajar peserta didik di MI At-Taqwa Bondowoso. Penggunaan model ARCS mampu merangsang semangat peserta didik dalam pembelajaran tematik. Sehingga peserta didik mampu belajar dengan semangat dan menyenangkan. Model ARCS tidak hanya menuntut guru untuk mengembangkan aspek kognitif peserta didik dalam pembelajaran, akan tetapi juga mengharuskan guru untuk mengoptimalkan semangat peserta didik dalam pembelajaran.

Keller (1983) telah menyusun seperangkat prinsip-prinsip motivasi yang dapat diterapkan dalam proses pembelajaran, yang disebut sebagai ARCS model yaitu Attention (perhatian), Relevance (relevansi), Confidence (kepercayaan diri), dan Satisfaction (kepuasan). Dalam proses belajar dan pembelajaran, keempat kondisi motivasional tersebut sangat penting dipraktikkan untuk terus dijaga sehingga motivasi peserta didik terpelihara selama proses belajar dan pembelajaran berlangsung.

1. Attention (perhatian), merupakan dorongan rasa ingin tahu. Rasa ingin tahu tersebut muncul karena dirangsang melalui elemen-elemen baru, aneh, lain dengan yang sudah ada, dan kodradiktif/kompleks. Terdapat beberapa strategi untuk merangsang minat dan perhatian peserta didik dalam proses pembelajaran, yaitu sebagai berikut.

a) Gunakan metode penyampaian yang bervariasi.

b) Gunakan media untuk melengkapi pembelajaran.

c) Gunakan humor dalam penyajian pembelajaran

d) Gunakan peristiwa nyata, anekdot dan contoh-contoh untuk memperjelas konsep yang diutarakan.

e) Gunakan teknik bertanya untuk melibatkan peserta didik .

2. Relevance (relevansi), merupakan adanya hubungan yang ditunjukkan antara materi pembelajaran, kebutuhan dan kondisi peserta didik. Ada tiga strategi yang dapat digunakan untuk menunjukkan relevansi dalam pembelajaran, yaitu sebagai berikut. 
a) Sampaikan kepada peserta didik apa yang akan dapat mereka lakukan setelah mempelajari materi pembelajaran.

b) Jelaskan manfaat pengetahuan/keterampilan yang akan dipelajari.

c) Berikan contoh, latihan/tes yang langsung berhubungan dengan kondisi peserta didik atau profesi tertentu.

3. Confidence (kepercayaan diri), merasa diri kompeten atau mampu merupakan potensi untuk dapat berinteraksi dengan lingkungan. Motivasi akan meningkat sejalan dengan meningkatnya harapan untuk berhasil. Ada sejumlah strategi untuk meningkatkan kepercayaan diri, yaitu sebagai berikut.

a) Meningkatkan harapan peserta didik untuk berhasil dengan memperbanyak pengalaman berhasil.

b) Menyusun pembelajaran ke dalam bagian-bagian yang lebih kecil, sehingga peserta didik tidak dituntut mempelajari banyak konsep sekaligus.

c) Meningkatkan harapan untuk berhasil dengan menggunakan persyaratan untuk berhasil.

d) Menggunakan strategi yang memungkinkan control keberhasilan di tangan peserta didik .

e) Tumbuh kembangkan kepercayaan diri peserta didik dengan pernyataan-pernyataan yang membangun.

f) Berikan umpan balik konstruktif selama pembelajaran, agar peserta didik mengetahui sejauh mana pemahaman dan prestasi belajar mereka.

4. Satisfaction (kepuasan), merupakan keberhasilan dalam mencapai suatu tujuan akan menghasilkan kepuasan, peserta didik akan termotivasi untuk terus berusaha mencapai tujuan yang serupa. Ada sejumlah strategi untuk mencapai kepuasan, yaitu sebagaiberikut.

a) Gunakan pujian secara verbal, umpan balik yang informatif, bukan ancaman atau sejenisnya. 
b) Berikan kesempatan kepada peserta didik untuk segera menggunakan/mempraktikkan pengetahuan yang baru dipelajari.

c) Minta kepada peserta didik yang telah menguasai untuk membantu teman-temannya yang belum berhasil.

d) Bandingkan prestasi peserta didik dengan prestasinya sendiri di masa lalu dengan suatu standar tertentu, bukan dengan peserta didik lain. ${ }^{9}$

Komponen penting dalam aktivitas pembelajaran adalah aktivitas pendahuluan, aktivitas inti, dan aktivitas penutup.

1. Mengembangkan Aktivitas Pembelajaran

a. Aktivitas Pendahuluan

Aktivitas pendahuluan merupakan suatu bentuk aktivitas awal untuk memberikan motivasi, menginformasikan pengetahuan dan keterampilan prasyarat yang harus dikuasai, dan tujuan atau standar kompetensi yang akan diperoleh dalam pembelajaran. Motivasi merujuk pada apa yang peserta didik inginkan, pilihan kegiatan yang dilakukan, dan komitmen yang diambil dalam hubungannya dengan pembelajaran. Pendekatan model ARCS diperkenalkan oleh John Keller untuk menjadi dasar dalam membangun motivasi peserta didik dalam pelaksanaan pembelajaran yang disimpulkan sebagai berikut:

$\mathrm{A}=$ Attention (perhatian)

$\mathrm{R}=$ Relevance (hubungan)

$\mathrm{C}=$ Confidence (keyakinan)

$\mathrm{S}=$ Satisfaction (kepuasan)

Membangun motivasi peserta didik dalam ruang kelas diperlukan model ARCS yang kemudian dijabarkan lebihjauh oleh Keller sendiri dalam Reiser dan Dempsey (2007). Setiap kategori memiliki beberapa sub kategori yang semuanya diformulasi dalam bentuk pertanyaan yang bersifat teknis untuk direnungkan oleh guru, dosen, atau instruktur.

${ }^{9}$ Nara , Teori Belajar dan Pembelajaran, 52-53 


\begin{tabular}{|c|c|}
\hline Perhatian & \\
\hline Minat persepsi & $\begin{array}{l}\text { Apa yang dapat saya lakukan untuk menarik } \\
\text { minat peserta didik? }\end{array}$ \\
\hline $\begin{array}{l}\text { Minat } \\
\text { penyelidikan }\end{array}$ & $\begin{array}{l}\text { Bagaimana saya dapat mendorong sikap } \\
\text { penyelidikan peserta didik? }\end{array}$ \\
\hline Beragam taktik & $\begin{array}{l}\text { Bagaimana saya dapat menggunakan berbagai } \\
\text { taktik untuk memelihara perhatian peserta } \\
\text { didik? }\end{array}$ \\
\hline \multicolumn{2}{|l|}{ Hubungan } \\
\hline Orientasi tujuan & $\begin{array}{l}\text { Bagaimana saya dapat memenuhi kebutuhan } \\
\text { peserta didik? }\end{array}$ \\
\hline Kecocokan tujuan & $\begin{array}{l}\text { Kapan dan bagaimana saya dapat } \\
\text { mempersiapkan peserta didik dengan pilihan, } \\
\text { tanggung jawab, dan pengaruh yang tepat? }\end{array}$ \\
\hline Kebiasaan & $\begin{array}{l}\text { Bagaimana saya dapat menghubungkan } \\
\text { pembelajaran dengan pengalaman peserta } \\
\text { didik? }\end{array}$ \\
\hline \multicolumn{2}{|l|}{ Keyakinan } \\
\hline $\begin{array}{l}\text { Persyaratan } \\
\text { belajar }\end{array}$ & $\begin{array}{l}\text { Bagaimana saya dapat membantu } \\
\text { menggambarkan harapan positif menuju } \\
\text { kesuksesan? }\end{array}$ \\
\hline $\begin{array}{l}\text { Kesempatan } \\
\text { keberhasilan }\end{array}$ & $\begin{array}{l}\text { Bagaimana pengalaman belajar dapat } \\
\text { menunjang keyakinan peserta didik terhadap } \\
\text { kompetensi mereka? }\end{array}$ \\
\hline $\begin{array}{l}\text { Pengawasan } \\
\text { personal }\end{array}$ & $\begin{array}{l}\text { Bagaimana peserta didik mengetahui bahwa } \\
\text { keberhasilan mereka betul-betul dari hasil } \\
\text { kerja keras dan kemampuan mereka? }\end{array}$ \\
\hline \multicolumn{2}{|l|}{ Kepuasan } \\
\hline Penguatan & Bagaimana saya dapat mempersiapkan \\
\hline
\end{tabular}




\begin{tabular}{|l|l|}
\hline intrinsik & $\begin{array}{l}\text { kesempatan yang berharga bagi peserta didik } \\
\text { untuk menggunakan pengetahuan dan } \\
\text { keterampilan yang baru dia peroleh? }\end{array}$ \\
\hline Hadiah ekstriksik & $\begin{array}{l}\text { Apa yang dapat dipersiapkan untuk } \\
\text { memberikan penguatan terhadap keberhasilan } \\
\text { peserta didik? }\end{array}$ \\
\hline Persamaan & $\begin{array}{l}\text { Bagaimana saya dapat membantu peserta } \\
\text { didik dalam mempertahankan perasaan positif } \\
\text { tentang prestasi mereka? }\end{array}$ \\
\hline
\end{tabular}

Tidak hanya pemberian motivasi, kegiatan pendahuluan juga mencakup kegiatan tentang perlunya menginformasikan pengetahuan prasyarat bagi peserta didik yang baru memulai suatu materi pembelajaran dan melakukan apersepsi jika pembelajaran telah memasuki pertemuan kedua atau lebih. Apersepsi adalah suatu proses membangun pemahaman tentang kualitas suatu objek yang berkaitan dengan pengalaman masa lalu. ${ }^{10}$

b. Aktivitas Inti

Kegiatan inti dilaksanakan sebagai proses pembelajaran untuk mencapai kompetensi dasar yang dilakukan secara interaktif, inspiratif, menyenangkan, menantang, memotivasi peserta didik untuk berpartisipasi aktif, serta memberikan ruang yang cukup bagi prakarsa, kreativitas, dan kemandirian sesuai dengan bakat, minat, dan perkembangan fisik serta psikologis peserta didik. Kegiatan ini menggunakan metode yang disesuaikan dengan karakteristik peserta didik dan mata pelajaran, yang meliputi proses eksplorasi, elaborasi, dan konfirmasi. ${ }^{11}$

\footnotetext{
${ }^{10}$ Yaumi, Prinsip - prinsip Desain Pembelajaran. 243-245

${ }^{11}$ Yaumi, Prinsip- prinsip Desain Pembelajaran. 246
} 
Dalam kurikulum 2013, semua kegiatan inti mengacu pada pendekatan yang digunakan seperti pendekatan saintifik (scientific instruction), pembelajaran berbasis masalah (problem based learning), dan pembelajaran berbasis projek (project-based learning). ${ }^{12}$

Selain penerapan pendekatan saintifik dalam pelaksanaan kegiatan inti pembelajaran, pendekatan lain dapat diracang untuk memberikan penjabaran lain dapat dirancang untuk memberikan penjabaran dari setiap tahapan kegiatan. Pendekatan lain yang dimaksud adalah pembelajaran tematik terpadu, pembelajaran berbasis masalah, dan pembelajaran berbasis projek.

c. Aktivitas Penutup

Aktivitas penutup merupakan kegiatan yang dilakukan untuk mengakhiri aktivitas pembelajaran yang dapat dilakukan dalam bentuk rangkuman atau kesimpulan, penilaian dan refleksi, umpan balik, dan tindak lanjut.

Dua kegiatan yang terdapat dalam aktivitas penutup, ialah: pertama, aktivitas penilaian mencakup aktivitas membuat rangkuman yang dapat dilakukan baik oleh guru sendiri maupun bersama-sama dengan peserta didik, begitu juga dengan kegiatan refleksi. Kedua, kegiatan tindak lanjut yang mencakup perencanaan, kemudian menyampaikan rencana pembelajaran yang akan datang dengan maksud agar peserta didik dapat mempersiapkan diri dengan berbagai tugas yang diberikan. Jika perlu, tugas membaca dan unjuk kerja perlu diinformasikan baik yang dilakukan secara online, kelompok atau mandiri, maupun dilakukan secara bertahap melalui petunjuk kerja dan lembar kerja peserta didik. ${ }^{13}$

\footnotetext{
${ }^{12}$ Yaumi, Prinsip -prinsip Desain Pembelajaran. 248

${ }^{13}$ Yaumi, Prinsip-prinsipDesain Pembelajaran, 251
} 


\section{SIMPULAN}

Dari pemaparan data dan analisisnya tentang: optimalisasi model ARCS dalam pembelajaran tematik untuk meningkatkan motivasi belajar peserta didik di MI At-Taqwa Bondowoso, dapat disimpulkan bahwa: (1) Problematika Pembelajaran Tematik di MI At-Taqwa Bondowoso, yaitu: Guru kurang terbiasa memanfaatkan media pembelajaran, sehingga sumber yang dipakai hanya buku ajar saja, Pembelajaran di kelas hanya berpusat pada guru, Kurangnya ketertarikan peserta didik dalam proses pembelajaran, sehingga peserta didik tidak memperhatikan guru yang mengajar. (2) Penerapan model ARCS dalam pembelajaran tematik di MI At-Taqwa Bondowoso, yaitu: Penerapan model ARCS dilakukan oleh para guru dengan beberapa metode dan strategi seperti strategi modeling the way dan juga contextual teaching and learning, Model ARCS sebaga solusi altenatif dalam pembelajaran untuk meningkatakn motivasi belajar peserta didik mampu merangsang semangat peserta didik dalam pembelajaran tematik.

\section{DAFTAR PUSTAKA}

Moleong, Lexy J. Metodologi Penelitian Kualitatif. Bandung: Remaja Rosdakarya, 2019.

Musfiqon. Panduan Lengkap Metodologi Penelitian Pendidikan. Jakarta: Prestasi Public Publiser, 2012.

Observasi Di Bondowoso 13 November 2020.

Pidarta, Mede. Landasan Kependidikan. Jakarta: Rineka Cipta, 2014.

Pribadi, Benny A. Model Desain Sistem Pembelajaran. Jakarta: PT :Kencana, 2009.

Ratumanan dan Imas Rosmiati. Perencanaan Pembelajaran. Depok : PT. Raja Grafindo Persada, 2019. 
Sinta Yulis Pratiwi dan Lailatul Usriyah, "Implementasi Pendidikan Profetik Dalam Membentuk Karakter Peserta Didik Di Sekolah Dasar AlBaitul Amien Jember". EDUCARE: Journal of Primary Education 1 (3), 2020.

Siregar, Eveline dan Hartini Nara. Teori Belajar dan Pembelajaran. Bogor :Ghalia Indonesia, 2010.

Suardi Wekke, Ismail. Ridha Windi Astuti. Kurikulum 2013 di Madrasah Ibtidaiyah Implementasi di Wilayah Minoritas Muslim. Tadris : Jurnal Keguruan dan Ilmu Tarbiyah 02. 2017.

Suranto. Pengaruh Motivasi, Suasana Lingkungan Dan Sarana Prasarana Belajar Terhadap Prestasi Belajar Peserta didik Studi Kasus Pada SMA Khusus Putri SMA Islam Diponegoro Surakarta. Jurnal Pendidikan Ilmu Sosial. Vol 25, No.2, Desember, 2015.

Yaumi, Muhammad. Prinsip-primsip Desain Pembelajaran. Jakarta: Kencana, 2016. 